\title{
Showcase preview
}

Please send trade news information and illustrations to Arveen Bajaj at the $B D J$,

Nature Publishing Group, The Macmillan

Building, 4-6 Crinan Street, London N1 9XW.

Trade news is provided as a service to readers using text and images from the manufacturer, supplier or distributor and does not imply endorsement by the $B D J$. Normal and prudent research should be exercised before purchase or use of any product mentioned.

\section{COUNTDOWN TO SHOWCASE}

The BDTA Dental Showcase takes place at the NEC, Birmingham from Thursday 12 November to Saturday 14 November 2009. A special research area will be set up within the hall for visitors to enjoy refreshments and take part in a focus group. There will also be questionnaires to complete.

Participants will receive the exhibition mascot to take home with them and will be entered into a prize draw for the

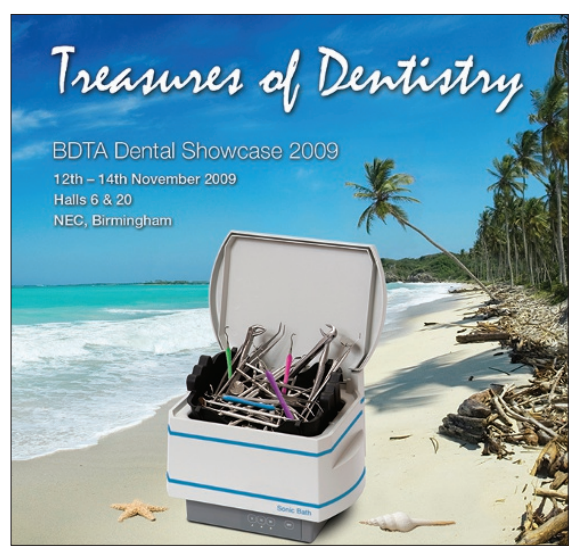

\section{EDUCATION AND TRAINING SOLUTIONS}

Delegates are invited to discover the latest approaches in education and training solutions that are flexible, involving and inspirational at the Smile-on stand L03 at Dental Showcase. Smile-on provides access to everything the dental team needs to meet their industry obligations and advance their skills, whatever level they are at in their career. Solutions include the Dental Photography Course, bringing dental professionals up to speed with the best methods of image capture, and chance to win a case of wine. The research will investigate participants' reasons for attending BDTA Dental Showcase 2009 and how visitors would like to see the event improved in the future.

There will also be a chance to have a team or individual photograph taken in a special beach-themed photography spot set up in the feature area to link in with the 'Treasures of Dentistry' theme being used to promote this year's Showcase. You will be able to download your photographs free from the Showcase website at www.dentalshowcase.com. Alternatively, you can request a print to be sent to you to frame in your practice or laboratory.

To register for your complimentary ticket visit www.dentalshowcase.com/ visit, call the registration hotline on +44 (0)1494 729959 or text your name, address, occupation and GDC number to 07786206 276. On-the-day registration is $£ 10$ per person.

Reader response number 50

the Communication in Dentistry Programme, which has just been expanded with the next three modules, exploring essential areas such as complaint handling, achieving consent and recording communication.

The Smile-on team will be ready to advise on all programmes including the popular DNSTART and DNNET 11, providing vital knowledge for dental nurses studying for the National Certificate or NVQ level 3 in Oral Health Care and which is also used as an update programme for established nurses.

Reader response number 51

\section{EYEWEAR AND INFECTION CONTROL}

\section{BLACKWELL B Supplies}

Blackwell Supplies will be exhibiting the new range of Hogies eyewear and infection control products at the BDTA Dental Showcase this year. At its stand, delegates will be able to discover the quality and magnification capability of Hogies MaximEyes loupes.

The unique MaximEyes design reduces the weight of the loupes on the nose by $70 \%$ for less neck strain and fatigue. The high quality lenses are designed with precision in mind, to suit all clinical requirements from general dentistry to endodontics or surgery. The new Hogies EyeGuards provide high performance protection with award-winning style, uncompromised safety and comfort.

Blackwell's team will also be on hand to explain the efficacy of the exclusively developed Bossklein range of alcohol-free disinfectants, which offer advantages over alcohol-based products while achieving infection control.

Bossklein Wet Wipes and Foam have a fast, potent bactericidal and anti-viral action against common pathogens found in the dental surgery and the range can be used for keeping Hogies clean without damaging them.

Reader response number 52 


\section{MULTIFUNCTION FOOT CONTROL}

The team at Castellini will be at stand E13 at Showcase demonstrating their current product range. Combining technology with design, delegates can view the new Duo package, designed for instrument accessibility and comfort through its ergonomic design.

The package boasts enhanced flexibility for the dental team, with added installation options including an LCD Control Panel, with the possibility to program functioning parameters for each working instrument, as well as a multifunction foot control for spray and instrument activation.

Visitors to the stand can also view the new Duo Luna HT operating light, with removable and autoclavable handles and the option to program the light for

\section{RESTORATION ADVANCEMENTS}

The team at CosTech Elite will be at Showcase to demonstrate their innovative restoration advancements such as Zirconarch, Thineers and Comflexin. Delegates can meet Elite managers David and Neil and discover how the team has become

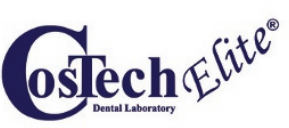

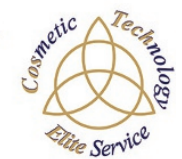

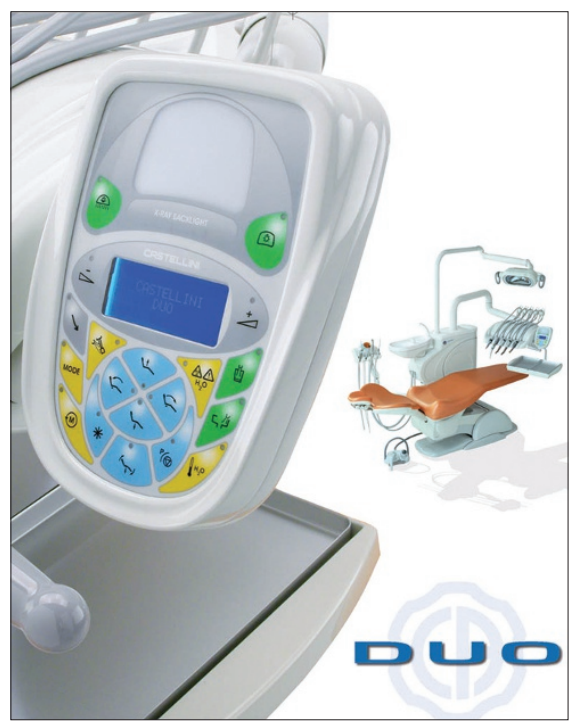

automatic switch on and off dependent on chair position.

Reader response number 53

the trusted eyes, ears, technical knowledge and quality control for the dentist.

Understanding that consistency is essential for the smooth running of your practice, the Elite managers work to bring you clear communication and consistent, quality work.

Visitors to the stand can also explore how CosTech Elite, now a Lava design studio, utilises Lava Scanner and 3M ESPE to create Lava Elite crowns. Its restorations and beautiful results come with a five year guarantee.

Reader response number 54

\section{BRUSH TO SUPPORT THE MOUTH CANCER FOUNDATION}

Philips is providing The Mouth Cancer Foundation with a dedicated area on its stand at the BDTA Exhibition. Visitors to the colourfully illuminated stand will be able to meet Dr Vinod Joshi and his blue ribboned team to find out more about the growing threat of mouth cancer.

The disease is diagnosed in 5,000 people annually and kills almost 2,000 each year - which is one person every five hours. It is statistics such as these which the charity wants to highlight to dental professionals who are on the front line in the early detection of the disease.
As well as providing practical support for the charity, Philips will be donating $£ 1$ to the Mouth Cancer Foundation for every person who brushes their teeth with a Sonicare FlexCare in one of three brushing booths located on the stand. In the past there have been queues around the stand to try the newest Sonicare brushes and if the same happens this year, a substantial donation will be made to the charity to help support its work.

To brush up on the latest facts visit stand J06. For more information about the charity visit www.mouthcancerawareness.org

Reader response number 55
COMPLETE RANGE OF TREATMENT CENTRES

Sident Dental Systems on stand V13 has the ultimate Sirona experience. Sirona specialists Sident Dental Systems offer the choice from the complete range of Sirona Treatment Centres, 2D and 3D digital imaging units - including the very latest Galileos 3D digital cone-beam equipment, their extensive range of handpieces, and auxiliary items including SiroLaser, SiroEndo and the DAC Universal sterilisation unit.

To support these items they offer Durr Suction and Dental Art cabinetry, as well as other essential equipment from similarly tried and trusted manufacturers. Wherever possible potential clients are invited to visit The Courtyard, Sident's state-of-theart training and showroom facility in Chertsey, where they will be able see the complete product range in action.

They will then be able to identify the best solution for their individual needs, allowing Sident's design specialists to incorporate their desires into the most appropriate and ergonomically efficient surgery or practice layout. Through their partner, Infiniti Finance plc, they can take the headache out of financing new equipment and installations, with finance packages tailored to individual requirements at very competitive rates.

Reader response number 56

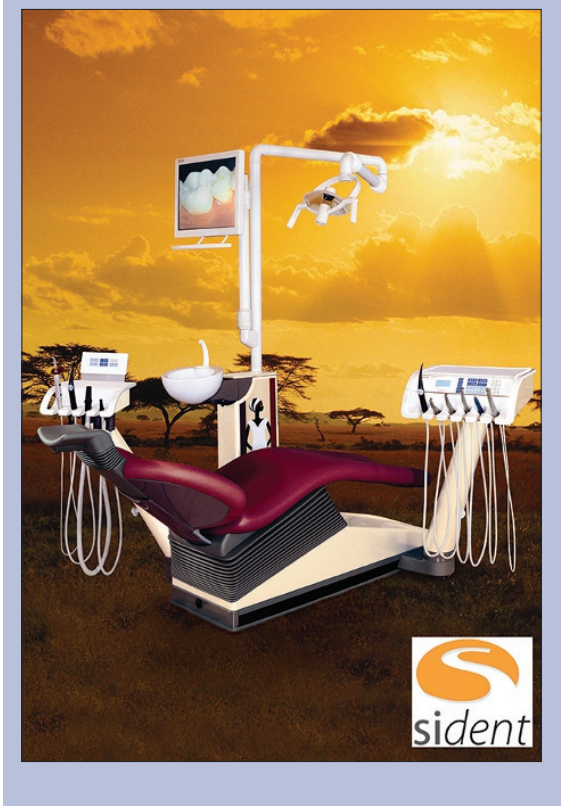




\section{DOWNLOADABLE PODCASTS ON TOPICAL SUBJECTS}

Delegates to the 2009 Dental Showcase can discover educational courses to take their knowledge and career to the next level with the UCL Eastman Dental Institute. The Eastman stand at R12 is the ideal setting for expert advice on continuing education through well-established and highly regarded courses. Delegates can also find out how the Eastman is offering new courses to proactively respond to changes within dentistry and patient demands.
It will be unveiling two exciting new initiatives. For DCPs there will be a range of downloadable podcasts on topical subjects, each with one hour of verifiable CPD. For dentists and all members of the dental team there will be an online package providing verifiable CPD for all core CPD topics.

Delegates will be able to explore Eastman's portfolio, which includes specialist training and Masters level programmes in addition to on-site or online CPD opportunities.

Reader response number 57

\section{sugh eastman}

\section{DISCOVER HOW TO ATTRACT NEW PATIENTS}

Munroe Sutton is bringing a Patient Referral Plan to stand T05 during Showcase, where delegates can discover how to attract new patients and enjoy the significant rewards of greater loyalty.

\section{Munroe}

International Dental Networks

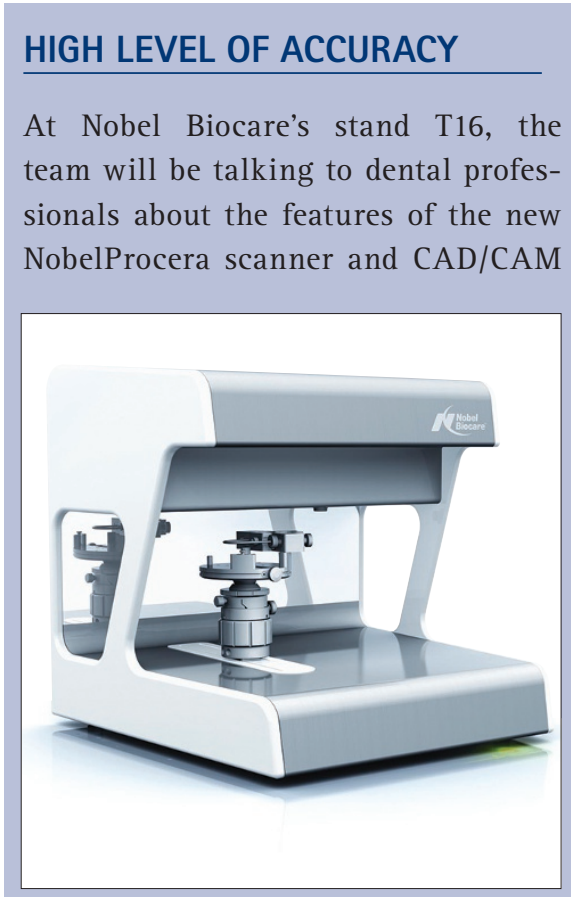

The Patient Referral Plan has been developed by dentists, for dentists and lets practices increase cashflow with payment at time of service, reach out to more patients with free marketing solutions, offers a seamless service with an automated patient verification system and has access to an exclusive aesthetic smile design system by smile designer Jason J. Kim.

Reader response number 58

software. Delegates should ask about the high level of accuracy achieved by the new optical scanner, and the intuitive employment of the system.

The team will explain the range of tools incorporated into the CAD/ CAM software suite, such as waxup, full anatomical bridge design and cutback and much more, all designed by dental professionals who inherently understand what they and their colleagues need from their equipment.

Nobel Biocare's specialists will discuss training options and the wealth of new materials available to support the innovative developments in technology and software.

Reader response number 59

\section{PALATABLE AND NON-STAINING}

Curasept Gel is back, and dental professionals attending the BDTA Dental Showcase 2009 are invited to explore the entire range from Curaprox. Providing a targeted application of $0.5 \%$ chlorhexidine, Curasept Gel easy to apply without patient compliance issues. Patients can even apply it themselves at home.

Delegates visiting stand P01 can enquire about the entire chlorhexidine range, including but by no means limited to alcohol-free ADS205, a non-staining fluoride and chlorhexidine rinse that is intended for daily use (0.05\% fluoride and 0.05\% chlorhexidine).

Also on display will be ADS705 gel toothpaste, also suitable for daily use. Free from sodium lauryl sulphate, ADS705 does not nullify the effects of chlorhexidine and is palatable and nonstaining. With $0.2 \%$ chlorhexidine it is intended for short-term use. Delegates should also ask about Enzycal, also free from sodium lauryl sulphate and featuring non-irritant steareth-30, perfect for patients presenting with aphthous ulcers, and the Curaprox portfolio of interdental brushes, toothbrushes and handy travel sets.

Reader response number 60

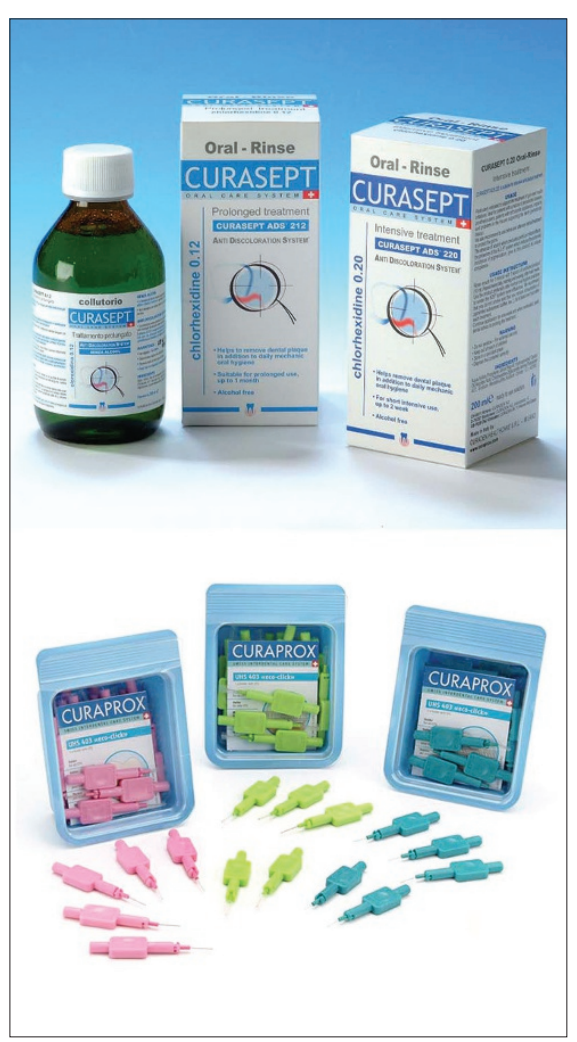




\section{WIN A RED LETTER DAY}

Delegates will be able to enjoy the benefits of specialist independent financial advice, as well as being entered into a draw for an exciting Red Letter Day out, courtesy of the money4dentists team at stand K18.

money4dentists will be offering delegates the chance to win $£ 200$ worth of vouchers, where the winner can choose from driving a supercar such as a Ferrari, a spa day, a hot air balloon flight and much more.

A visit to the stand will also offer delegates exclusive access to money4dentists'

\section{ESSENTIAL EQUIPMENT SOLUTIONS}

Nuview provides practices with a high quality range of equipment solutions and offers a comprehensive service. At its stand on L05, technology available includes the OPMI Pico dental microscope, designed by Carl Zeiss, and the EyeMag range of loupes including the EyeMag Smart, with $2.5 \times$ magnification and a choice of working distances.

This is also a great opportunity to discover alcohol-free and 99.999\% effective disinfectant Continu, ideal for practitioners and patients in the wake of the Swine Flu alert, and the latest addition to the Continu range, the

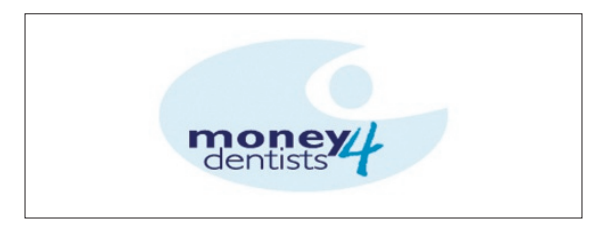

knowledge and experience. The team will provide reliable strategies for investment and pension planning, methods to safeguard the future of dependents and children, and ways to minimise tax through the use of income tax allowances, capital gains allowances, saving plans and gifts and how to reduce your income tax to zero.

Reader response number 61

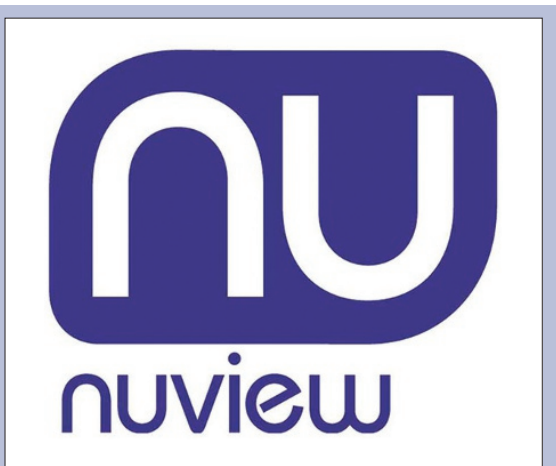

Anti Microbial Dental Impression Mix, which disinfects impressions at source and inhibits contamination for weeks. Nuview will additionally be displaying Swiss-designed Everclear, a dental mirror that self-cleans.

Reader response number 62

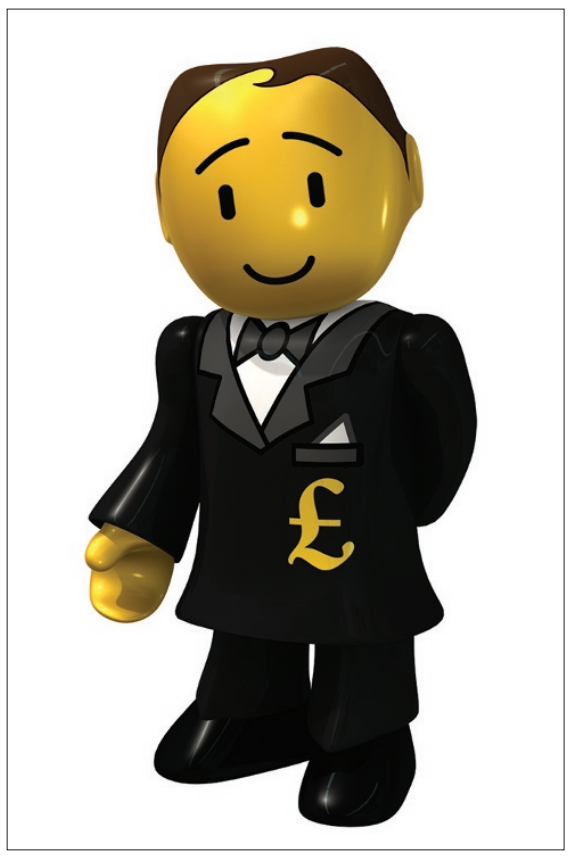

\section{INVEST IN YOUR PRACTICE WITH A COOL MILLION}

One lucky dentist, hygienist, practice manager, nurse or therapist could walk off with a million pounds, as Dentsply have teamed up with a major company to indemnify this sum to help you invest in the practice you have always wanted.

No purchase is necessary, you simply fill out a five minute questionnaire at www.dentsply.co.uk and you will be automatically entered into the draw.

Ten finalists will then be selected at the end of October and the final winner will be drawn at the BDTA Dental Showcase on Saturday 14 November at $12 \mathrm{pm}$. The finalist will have the chance to win either $£ 1$ million, £100,000, £10,000 or at the very least $£ 5,000$.

\section{HIGH-RESOLUTION NAVIGATION TOUCH-SCREEN}

Henry Schein Minerva's team of experienced consultants at stand S06 can offer advice on every aspect of running a successful practice, recommending and helping you implement solutions that are tailor-made to suit your individual and practice needs.

As your practice goes from strength to strength, Henry Schein Minerva will continue to play an important role in your business, supporting you in achieving your desired personal and practice goals.

You can experience the company's products and services at Showcase. Its Biolase Waterlase MD laser effectively combines YSGG laser energy and water so you can perform both hard and soft tissue procedures with less anaesthesia, making your patients' visits to the dentist a far more comfortable experience.

The laser has been well-designed with help and advice from laser users throughout the world, and has a highresolution navigation touch-screen and LaserPal help system.

Reader response number 64

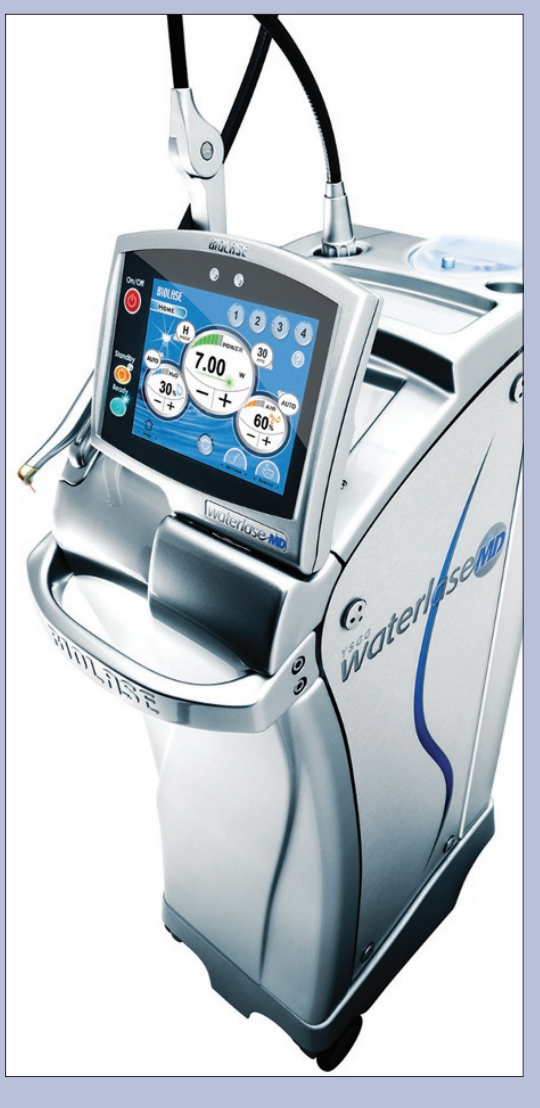




\section{WIN A FLAT SCREEN HD TV}

To celebrate the launch of their new website, Dental Sky have a 50" Samsung Flat Screen HD television to give away to one lucky customer. To enter the competition, visit the Dental Sky website www.dentalsky.com and submit your contact details; you will then be automatically entered into the draw and be in with a chance of winning the prize.

The prize draw will be open until $2 \mathrm{pm}$ on the 14 November 2009, when the draw will take place on the Dental Sky stand at Showcase. In keeping with this year's 'Treasures of Dentistry' theme

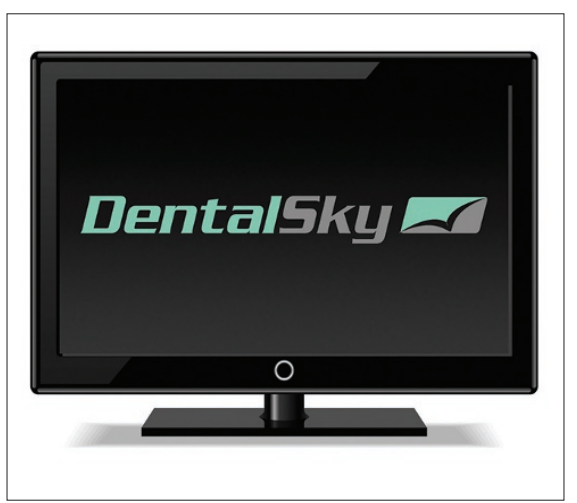

the winner will be picked at random by Captain Jack Sparrow of Pirates of the Caribbean fame.

Reader response number 65

\section{DENTAL DECONTAMINATION ROOM CABINETRY}

Delegates looking for the latest comprehensive instrument decontamination solutions should not miss a visit to stand N19 where Eschmann will be displaying its products and equipment.

The team will be on hand to demonstrate the advantages of their fully HTM 01-05 compliant equipment and their new range of Decon360 dental decontamination room cabinetry.

Decon360 demonstrates Eschmann's all-encompassing approach to providing the total package that will allow all dentists to fully comply with HTM 01-05, whatever the size of their surgery.

\section{(A) ESCHMAN}

The Little Sister range of autoclaves features dual processors for independent cycle monitoring together with state of the art air detection. The high performance washer disinfector dryers include Eschmann's unique directional hand piece irrigation for excellent cleaning of complex, lumened instruments. The system has been developed to provide more effective cleaning of the internal lumens and heads of handpieces than traditional single flow systems.

Reader response number 66

\section{SIMULTANEOUS \\ SUCTION CAPACITY}

Dürr Dental will be unveiling a new product at this year's Dental Showcase exhibition, as well as giving practitioners the opportunity to see products launched earlier this year. One such product is the VS1200 S suction system, a multi-surgery solution that can

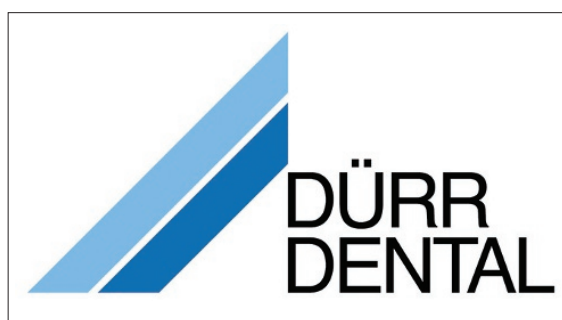

provide simultaneous suction capacity for up to six treatment rooms and four operators and will provide reliable spray-mist suction at a rate of 1,200 litres per minute.

The Power Tower Silence 120 (PTS 120) unit offers the versatility of a wet suction system (the Dürr VS type) or a dry option (the Dürr V type) where the functionality separates air and water.

The new PTS 120 is no louder than a standard dishwasher and in size no larger than a fridge, meaning you can get state of the art technology and maximum efficiency all from a device you could fit in your kitchen.

Reader response number 67 


\section{PATIENT RECALL THROUGH EMAIL AND SMS}

Version 10 of Software of Excellence's practice management system, Exact, designed to improve the efficiency of all dental practices. Features include patient recall through email and SMS communications, computer telephony integration (CTI), 3D teeth charting, multicolumn appointment books and much more.

Combine this with the new patient education resource Guru, which enables you to further develop or simplify your patients' individual explanations through various forms of media, and you have a practice management system which helps you to stay in complete control of your practice.

\section{PROTECT AND WHITEN TEETH}

The Beverly Hills Formula range from Purity Laboratories offers a unique combination of antibacterial agents, low abrasion and anti-stain polishers to protect and whiten teeth, and aims to provide innovative, high quality, niche products in the oral hygiene market.

Beverly Hills Formula Toothpaste can effectively remove tooth staining and offers maximum whitening power, includes a range of innovative features

Find out all you need to know about the system at stands R01, S05 and T04 where there is the added bonus of receiving a $£ 2,000$ voucher to spend with the company or Henry Schein Minerva simply by upgrading to Exact.

Reader response number 68

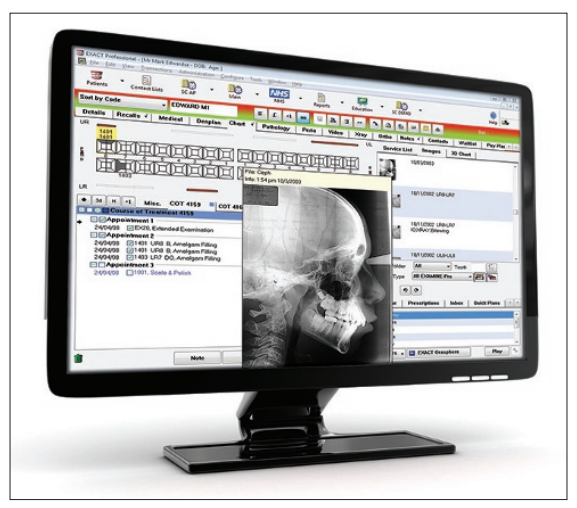

while maintaining extremely low abrasion. Total Protection is a dual action anti-bacterial formula to help fight plaque, tooth decay and bad breath. The Sensitive formulation is designed for people who suffer from sensitive teeth, whilst Breath Confidence fights bad breath for hours. The Natural formulation, with aloe vera and echinacea, offers natural gum protection, excellent whitening power and no artificial colouring or flavours.

Reader response number 69

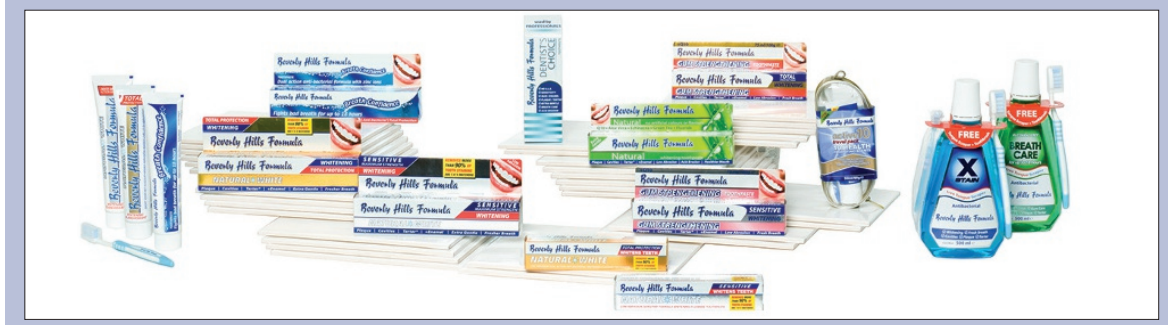

\section{NEW PROFESSIONAL ONLY PACKS}

P\&G Professional Oral Health will be showcasing their new Professional Only Packs at this year's BDTA Exhibition. P\&G know that products sold in practices are often demonstrated to patients to ensure they are being used correctly. As this takes time and effort, in recognition of this they will include a free educational DVD and the whole Oral-B range of seven replacement heads with every Professional
Care and Triumph power product sold.

The launch of these packs coincides with some upgrades. At the top is still Triumph SmartGuide, which has been re-branded 'Triumph 5000 SmartGuide'. Next is 'Professional Care 3000', which has been streamlined and has the addition of a large sensor on the rear of the handle that will illuminate if too much pressure is applied. The Professional Care 550 offers more basic functionality.

Reader response number 70

\section{SOFT TISSUE}

MANAGEMENT LASERS

QuickLase soft tissue management lasers can be used for many procedures like crown lengthening, veneer re-contouring, impressions troughing and more. The QuickWhite brand for teeth whitening is well known for its in-surgery effectiveness and home top-ups using both hydrogen and carbamide peroxide. Visit stand R02 to see live presentations and see the show special offers.

Reader response number 71

\section{QuickWhite QuickLase}

\section{BOOK A LUNCH AND LEARN}

Wright Cottrell dental suppliers' experienced team will be available on stand H04 to offer professionals advice and information about the very latest solutions.

Ensuring that clients have the choice and the quality to achieve their aims, Wright Cottrell will help delegates explore the extensive range of the latest sundries and cutting edge equipment featuring live demonstrations of the new Kavo Everest CAD/CAM technology - the complete processing system for strong and highly aesthetic all ceramic restorations.

Professionals are encouraged to visit the Wright Cottrell stand and discover the benefits of this solution for themselves, and book a lunch and learn for 1 hour of verifiable CPD. Reader response number 72

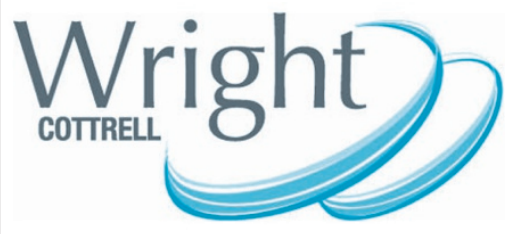

